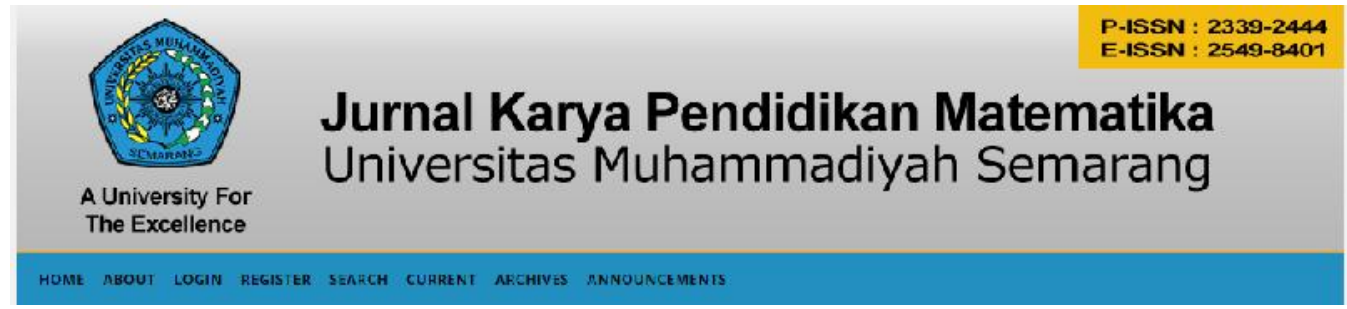

\title{
KOMPARASI MODEL PEMBELAJARAN TEMATIK INTEGRATIF BERBASIS DAERAH TEMPAT TINGGAL SEKITAR DENGAN BERBASIS KEMENDIKBUD UNTUK MENGUKUR HASIL BELAJAR SISWA KELAS 4
}

\author{
Oleh : \\ tri mulyani ${ }^{1)}$, mawardi ${ }^{2}$, krisma widi $^{3)}$ \\ universitas kristen satya wacana salatiga \\ 292015137@student.uksw.edu, mawardi@staff.uksw.edu,krisma.uksw@gmail.com
}

\begin{tabular}{|c|c|}
\hline Article history & Abstract \\
\hline Subm & wether there is an increase in \\
\hline & sed thematic \\
\hline Accepeted $: 4 / 4 / 19$ & $\begin{array}{l}\text { models of residential areas compared to MoEC-based learning } \\
\text { in 4th grade elementary school learning. The type of research } \\
\text { used is real research (true experimental). The sample of this } \\
\text { study was 4th grade students of SDN Pasekan 03 as an } \\
\text { experimental group. The data analysis technique used the }\end{array}$ \\
\hline Кеу & average difference test ( $t$ test). The normality of the \\
\hline & group was \\
\hline daerah & $\begin{array}{l}\text { 0.434.> } \\
\text { homoge }\end{array}$ \\
\hline tinggal & The \\
\hline kemendikbud, & $\begin{array}{l}\text { results showed } t \text { count } 1604 \text { with a signifi } \\
<0.05 \text {, so Ha accepted means that the learnin }\end{array}$ \\
\hline pembelajaran & $\begin{array}{l}\text { area-based housing around higher than the Ministry of } \\
\text { Education and Culture. }\end{array}$ \\
\hline
\end{tabular}

\section{Pendahuluan}

Pembelajaran di sekolah dasar dibagi menjadi dua tingkatan yaitu tingkatan kelas tinggi dan tingkatan kelas rendah. Kelas rendah terdiri dari kelas 1, 2 dan 3 sedangkan kelas tinggi terdiri dari kelas 4,5 dan 6. Sesuai dengan pernyataan dalam Permendikbud tahun 2016 No.22 tentang standar poses menjelaskan tentang proses pembelajaran dalam setiap satuan pendidikan diselenggarakan secara menyenangkan,interaktif, menantang,inspiratif dan memotivasi siswa dalam belajar. Oleh karena itu pemerintah berinovasi dengan cara merubah kurikulum KTSP menjadi kurikulum 2013 yang menggunakan model pembelajaran tematik.

Pembelajaran tematik merupakan pembelajaran yang berkaitan dengan suatu tema yang berupa objek atau topik yang dijadikan 
pokok pembahasan. Permendikbud No. 57 Tahun 2014 mengartikan pembelajaran tematik adalah salah satu model pembelajaran terpadu yang menggunakan tema untuk mengaitkan beberapa mata pelajaran sehingga dapat memberikan pengalaman bermakna bagi peserta didik. Di dalam kurikulum 2013 menggunakan model pengembangan kurikulum bebasis kompetensi yang sudah ditetapkan oleh pemerintah. Dalam kurikulum ini guru diberikan buku guru dan buku siswa sebagai pedoman dalam melaksanakan kegiatan pembelajaran.

Implementasi kurikulum 2013 saat ini senantiasa guru berpedoman kepada Buku Guru dan Buku Siswa dari Pemerintah. Kesibukan Guru mengajar sesuai dengan Buku Guru dan mengejar Pembelajaran agar tepat pada waktu yang telah di tetapkan oleh sekolah dan pemerintah membuat guru kurang menganalisis lebih jauh buku dalam proses pemebelajaran guru masih menggunakan pembelajaran konvensional dengan ceramah dan penugasan dengan bantuan buku guru dan buku siswa dari pemerintah. Padahal pada kurikulum 2013 siswa di tuntut aktif dalam memperoleh pengetahuanya sendiri,baik menggunakan buku siswa atau sumberlain.akan tetapi karena kurangnya pendalaman materi membuat siswa kesulitan mendapatkan pengetahuannya sendiri ini dapat disiasati dengan mengembangkan pembelajaran tematik yang menuntut siswa aktif dalam pembelajaran dengan penggunaan tema yang di sesuaikan dengan lingkungan siswa sendiri.

Tema yang perlu dikembangkan salah satunya yaitu Tema 4 Berbagai Pekerjaan Subtema 1 Jenis Jenis Pekerjaan Materi Kelas IV (Empat). berdasarkan analisis buku guru kelemahan terletak pada kedudukan dan fungsi buku guru yang dijadikan sebagai panduan bagi guru dalam melaksanakan pembelajaran di kelas. Pemberlakuan Kurikulum 2013 pada jenjang SD/MI secara bertahap memberikan cukup waktu bagi guru untuk mendesain pembelajaran tematik terpadu secara lebih bermakna. Pembelajaran tematik hakikatnya merupakan model pembelajaran yang memadukan beberapa mata pelajaran ke dalam tema (Trianto, 2009: 84).

Pembelajaran tematik berfungsi memberikan kemudahan bagi peserta didik dalam memahami dan mendalami konsep yang tergabung dalam tema serta dapat menambah semangat belajar karena materi yang dipelajari merupakan materi yang nyata (kontekstual) dan bermakna bagi peserta didik (Kemendikbud, 2014: 15). Ciri-ciri pembelajaran tematik menurut Mustamilah (2015:93-94) sebagai berikut : pembelajaran berpusat pada siswa, pembelajaran memberikan pengalaman secara langsung kepada siswa.

Selanjutnya pembelajaran bermakna menurut Koh, J.H.L. (2017: 136) menyatakan “...meaningful learning refers to learning that involves the active participation of students in experiences that are cognitively engaging ...".Pembelajaran bermakna mengacu pada pembelajaran yang melibatkan partisipasi aktif siswa dimana pengalaman pembelajaran tersebut menarik secara kognitif.

Pembelajaran yang kontekstual dan dapat memberikan pengalaman yang bermakna kepada siswa bisa dilakukan dengan mengkaitan lingkungan siswa atau daerah tempat tinggal siswa. Penelitian tentang pembelajaran tematik dengan mengkaitkan lingkugan siswa telah dilakukan oleh: Yusinta Dwi Ariyani dan Muhammad Nur Wangid (2016) menunjukkan hasil bahwa bahan ajar tematik integratif dengan tema "Lingkunganku Bersih dan Sehat" berbasis nilai karakter peduli lingkungan dan tanggung jawab untuk meningkatkan berpikir kritis serta nilai karakter peserta didik kelas 1 sekolah dasar.

Penelitian ini sejalan dengan penelitian yang dilakukan oleh Mulyadi, Marzuki, Andi (2015) bahwa preskriptif tugas belajar dilakukan guru dalam pembelajaran tematik terpadu berbasis lingkungan sangat membantu peserta didik untuk memperoleh kemampuan berpikir tingkat tinggi. Selanjutnya penelitian tentang pengembangan desain pembelajaran telah dilakukan oleh. Pringgondani A.T.W. (2016) menunjukkan signifikan terhadap hasil belajar siswa pada uji coba terbatas diperoleh hasil nilai T hitung sebesar 4.118dengan nilai $\alpha=0,000<$ 0,05. Artinya kompetensi hasil belajar menggunakan Model Desain Pembelajaran Tematik Integratif Berbasis Lingkungan lebih tinggidaripada model desain pembelajaran tematik integratif dari Pemerintah. Pembuktian yang sama, juga dilakukan penelitian tentang desain pembelajaran tematik bermakna yang 
dilakukan oleh mawardi (2019: 48-61) dan memperoleh hasil Rerata tingkat kebermaknaan belajar siswa pada uji lapangan terbatas meningkat dari 49,49 pada pretes menjadi 69,44 pada saat dilakukan postes. Pada Uji lapangan luas peningkatan kebermaknaan belajar siswa meningkat lebih besar dari 47,98 pada saaat dilakukan pretes menjadi 70,43 pada saat postes. Uji statistik menggunakan uji $\mathrm{t}$ memastikan bahwa peningkatan tersebut signifikan, karena nilai probabilitas $(0,00)$ lebih kecil dari nilai $\alpha=$ 0,05. Dengan demikian model desain pembelajaran ini layak digunakan dalam pembelajaran di kelas rendah maupun dikelas tinggi, sehingga dapat dikatakan model desain pembelajaran tematik integratif berbasis lingkungan memang tepat diterapkan dalam pembelajaran di Sekolah Dasar.

Desain Pembelajaran tematik integratif ini juga nampak pada siswa kelas 4 di SD Negeri Pasekan 02 dan SD Negeri Pasekan 03 Ambarawa. Pembelajaran IPS pada materi jenis - jenis pekerjaan yang berlangsung di SD Negeri Pasekan 02 yaitu menggunakan desain pembelajaran konvensional yang terpaku pada guru dimana guru selalu menjelaskan materi dan siswa hanya mendengarkan penjelasan kemudian di beri soal untuk mengerjakan baik secara individu maupun kelompok dengan panduan buku guru dan buku siswa. Kegiatan pembelajaran ini dilaksanakan terus menerus sehingga tidak ada variasi desain pembelajaran yang menyebabkan siswa kurang aktif dan cenderung bosan kemudian hasil belajar pun kurang meningkat. Kondisi proses pembelajaran seperti ini perlu ditingkatkan dengan mencoba desain atau model pembelajaran yang lain, salahsatunya dengan model berbasis daerah tempat tinggal sekitar.

Model pembelajaran merupakan suatu kerangkan, cara atau teknik dalam kegiatan belajar untuk mencapai tujuan pembelajaran tertentu. Model pembelajaran yang dilakukan oleh guru diharapkan bisa memberikan pengalaman belajar yang bermakna bagi siswa setelah melakukan pembelajaran tertentu. Salah satu contoh model pembelajaran yaitu model pembelajaran tematik integratif berbasis lingkungan daerah tempat tinggal sekitar.

Model pembelajaran tematik berbasis daerah tempat tinggal sekitar adalah suatu konkretisasi teori yang dibangun berdasarkan desain pembelajaran Kemendikbud (2014: 17), dengan memadukan lingkungan sebagai tema atau setting pembelajaran, dan pembelajaran tematik integratif yang berisi konstruk, tujuan dan langkah-langkah. Konstruk desain pembelajaran tematik integratif berbasis daerah tempat tinggal sekitar adalah rancangan sistematis konsep pembelajaran dengan menggunakan lingkungan sebagai tema untuk memberikan pengalaman bermakna bagi peserta didik.langkah pembelajaran tematik integratif yang telah dipadukan dengan pembelajaran berbasis daerah tempat tinggal sekitar. yaitu memilih tema dengan memperhatikan kaitannya dengan mata pelajaran.

Penentuan tema mengikuti prinsip penentuan tema, antara lain: 1. Memperhatikan lingkungan yang terdekat dengan siswa 2 . Memperhatikan dari termudah menuju ke sulit 3. Mulai dari yang sederhana menuju yang kompleks 4. Mulai yang konkret menuju ke yang abstrak. 5. Tema yang dipilih harus memungkinkan terjadinya proses berpikir pada diri peserta didik. 6. Ruang lingkup tema disesuaikan dengan usia dan perkembangan peserta didik, termasuk minat, kebutuhan peserta didik, termasuk minat, kebutuhan, dan kemampuannya. Setelah menentukan tema dilanjut membuat RPP.

Penyusunan RPP Pembelajaran Tematilk Langkah mengembangkan Rencana Pelaksanaan Pembelajaran (RPP) Tematik Integratif Berbasis lingkungan atau daerah tempat tinggal sekitar yaitu sebagai berikut: 1 . Mengkaji Silabus Tematik 2. Mengidentifikasi materi pembelajaran kegiatan mengidentifikasi materi pembelajaran dilakukan dengan mengkaji buku guru dan buku siswa untuk SD, dalam mengkaji guru memiliki wewenang untuk mengembangkan 3.Kegiatan pembelajarannya dikaitkan dengan lingkungan siswa. Setelah Penyususan RPP dilakukan implementasi nya yaitu pembelajaran dikelas dan diluar kelas dengan observasi di lingkungan sekitar daerah tempat tinggal siswa.

Tujuan dilakukan pembelajaran dengan model pembelajaran berbasis daerah tempat tinggal sekitar yaitu siwa akan lebih aktif dengan melakukan pengamatan atau observasi, 
mendapatkan ilmu pengetahuan serta pengalaman yang lebih bermakna dan dapat mengenal lingkungan disekitar yang dapat dimanfaatkan sebagai kegiatan belajar salah satunya tentang materi pembelajaran jenis-jenis pekerjaan. Sehingga diharapkan hasil belajar siswa akan lebih meningkat dengan model pembelajaran berbasis daerah tempat tinggal sekitar. dilihat dari hasil tes dan perbandingan model pembelajaran yang hanya terpaku pada penjelasan guru di kelas yang berpedoman buku guru dari kemendikbud.

Penjelasan lebih rinci dapat dilihat pada kerangka berpikir penelitian ini melalui gambar 1 skema penelitian model berbasis daerah tempat tinggal sekitar dengan berbasis kemendikbud terhadap peningkatan hasil belajar siswa.

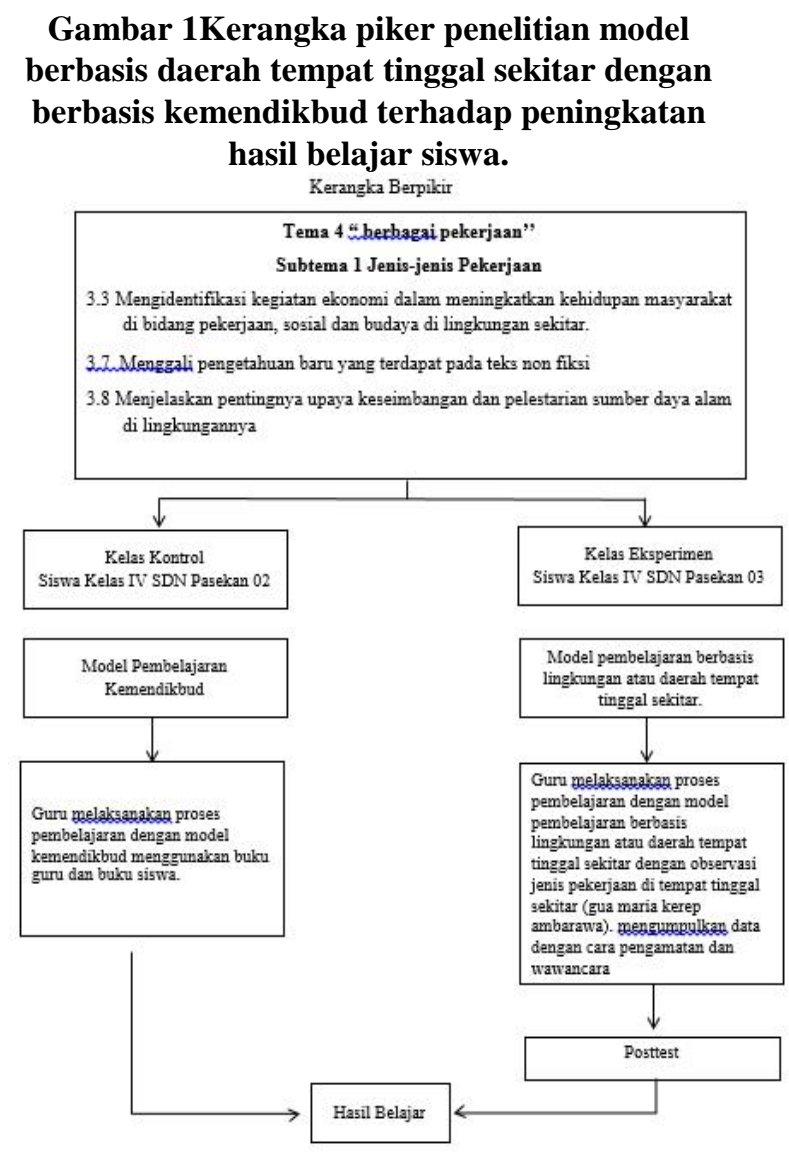

\section{MetodePenelitian}

Penelitian ini dilakukan di SD Negeri Pasekan 02 dan SD Negeri Pasekan 03 Ambarawa pada semester 2 tahun ajaran
2018/2019. Subjek penelitian yaitu siswa kelas 4 SD dengan jumlah 55 siswa.

Jenis penelitian yang digunakan adalah penelitian eksperimen sesungguhnya (true eksperimental). Penelitian eksperimen ini bertujuan untuk membuktikan apakah ada peningkatan hasil belajar dengan menggunakan model berbasis daerah tempat tinggal sekitar dibandingkan dengan kemendikbud. Subyek penelitian terdiri dari dua kelompok yaitu kelompok eksperimen yang diberi perlakuan model berbasis daerah tempat tinggal sekitar dan kelompok kontrol yang tanpa perlakuan dengan pembelajaran konvensional yang menggunakn buku guru.

Populasi dalam penelitian ini adalah seluruh siswa kelas 4 SD Pasekan Gugus Sidik Wacana kecamatan Ambarawa. Teknik pengambilan sampel menggunakan teknik random sampling (secara acak) Teknik ini yaitu pengambilan sampel atau elemen secara acak, yakni memilih lokasi Gugus Sidik Wacana kecamatan Ambarawa dan memilih 2 sekolah yaitu SDN Pasekan 02 dan SDN Pasekan 03 Ambarawa. (random sampling) yang mengambil seluruh sampel seluruh siswa kelas 4 .

Variabel yang digunakan dalam penelitian ini terdiri dua variabel, yaitu variabel bebas (X), variabel terikat (Y). Variabel bebas (independent) merupakan tindakan yang mempunyai pengaruh terhadap variabel terikat (dependent). Variabel terikat (Y) merupakan hasil belajar. dalam penelitian ini variabel bebasnya $(\mathrm{X})$ yaitu pembelajaran tematik menggunakn model berbasis daerah tempat tinggal sekitar. sedangkan hasil belajar merupakan variabel terikat (Y) yang muncul karena pengaruh variabel bebas.

Teknik pengumpulan data berupa observasi wawancara dan tes. Teknik tes digunakan untuk mengukur hasil belajar. Jenis tes pada penelitian ini yaitu tes objektif (pilihan ganda). Butir soal diujikan terlebih dahulu ke siswa kelas 4 SD N Kutowinangun 08 Salatiga yang bukan merupakan subjek penelitian. Uji coba bertujuan untuk mengetahui apakah instrument penelitian ini Valid dan reliabel sehingga layak digunakan untuk penelitian, sedangkan teknik berupa 
observasi, wawancara berupa lembar observasi digunakan untuk mengetahui proses pembelajaran yang berlangsung.

Teknik analisis data yang digunakan adalah teknik uji t. Persyaratan uji $t$ adalah ke dua kelompok adalah homogen dan berdistribusi normal. Untuk mengetahui homogenitas dan normalitas, maka instrumen penelitian perlu diketahui validitas dan reliabilitasnya terlebih dahulu. Pengolahan data dibantu dengan SPSS 20.0. butir soal dinyatakan valid apabila : koefisien korelasi (r) 0,30 dan apabila koefisien korelasinya $<0,30$ maka dinyatakan tidak valid (Azwar,2011:158). Hasil validitas butir soal posttest terdapat 20 butir soal yang valid dengan korelasi antara 0,365-0,713. Reliabilitas butir soal posttes menunjukkan hasil uji reliabilitas sebesar 0,84 sehingga angka koefisien ini sangat reliabel.

Langkah selanjutnya menguji normalitas dan homogenitas. Distribusi normal kelompok kontrol dan kelompok eksperimen dapat dilihat pada tabel 1 berikut ini.

Tabel 1. Distribusi normalitas hasil belajar kelompok kontrol dan kelompok eksperimen

\begin{tabular}{|c|c|c|c|}
\hline \multicolumn{4}{|c|}{ One-Sample Kolmogorov-Smirnov Test } \\
\hline & & $\begin{array}{c}\text { kelompo } \\
\text { k_kontr } \\
\text { ol }\end{array}$ & $\begin{array}{l}\text { kelompok_ } \\
\text { eksperimen }\end{array}$ \\
\hline \multicolumn{2}{|l|}{$\mathrm{N}$} & 25 & 30 \\
\hline \multirow{2}{*}{$\begin{array}{l}\text { Normal } \\
\text { Parameters }{ }^{\mathrm{a}, \mathrm{b}}\end{array}$} & Mean & 68.4800 & 82.0333 \\
\hline & $\begin{array}{l}\text { Std. } \\
\text { Deviati } \\
\text { on }\end{array}$ & 5.95203 & 6.44597 \\
\hline \multirow[t]{3}{*}{$\begin{array}{l}\text { Most Extreme } \\
\text { Differences }\end{array}$} & $\begin{array}{l}\text { Absolut } \\
\mathrm{e}\end{array}$ & .174 & .157 \\
\hline & Positive & .174 & .157 \\
\hline & $\begin{array}{l}\text { Negativ } \\
\mathrm{e}\end{array}$ & -.099 & -.110 \\
\hline \multicolumn{2}{|c|}{ Kolmogorov-Smirnov Z } & .871 & .861 \\
\hline \multicolumn{2}{|c|}{ Asymp. Sig. (2-tailed) } & .434 & .449 \\
\hline a. Test distribut & & & \\
\hline
\end{tabular}

Hasil uji normalitas hasil belajar tematik menggunakan teknik Kolmogorov-Smirnov Test dengan jumlah subjek yang digunakan uji normalitas sebanyak 25 siswa untuk kelompok kontrol, sedangkan kelompok eksperimen sebanyak 30 siswa. total subjek ada 55 siswa. Signifikansi kelompok kontrol sebesar 0,434 $>0,05$ maka kelompok kontrol berdistribusi normal. Dan hasil signifikansi kelompok eksperimen sebesar $0,449>0,05$ maka kelompok eksperimen berdistribusi normal.

Homogenitas untuk mengetahui homogenitas kedua kelompok yaitu kelompok kontrol dan kelompok eksperimen dilakukan dengan pengujian uji homogenitas. Hasil uji homogenitas kelompok kontrol dan kelompok eksperimen dapat dilihat melalui tabel 2 berikut ini.

Tabel 2. Homogenitas kelompok kontrol dan kelompok eksperimen

\begin{tabular}{crrrr}
\hline $\begin{array}{l}\text { Levene } \\
\text { statistic }\end{array}$ & \multicolumn{1}{c}{ df1 } & \multicolumn{1}{c}{ df2 } & \multicolumn{1}{c}{ Sig. } \\
\hline $\mathbf{. 0 3 4}$ & 1 & 53 & .855 \\
\hline Sumber & SPSS 20.0 & & & \\
\hline
\end{tabular}

Hasil uji homogenitas kelompok kontrol dan kelompok eksperimen ditunjukkan oleh signifikansi $0,855>0,05$ maka kelompok kontrol dan kelomok eksperimen adalah homogen.

\section{Hasil Dan Pembahasan}

Penelitian ini merupakan jenis penelitian eksperimen yang menggunakan dua kelompok yaitu kelompok kontrol dan kelompok eksperimen. Kelompok kontrol di lakukan di SD Negeri Pasekan 02 Ambarawa tanpa perlakuan dengan pembelajaran konvensional menggunakan model kemendikbud, dengan jumlah siswa 25. Kelompok eksperimen dilakukan di SD Negeri Pasekan 03 dengan menggunakan model tematik integratif berbasis daerah tempat tinggal sekitar, dengan jumlah siswa 30. Penelitian ini bertujuan untuk mengetahui apakah terdapat peningkatan hasil belajar menggunkan model tematik integratif berbasis daerah tempat tinggal sekitar dibandingkan dengan model kemendikbud. hasil belajar kelompok kontrol dan kelompok eksperimen dapat dilihat pada tabel 3 berikut. 
Tabel 3. Distribusi hasil belajar tematik kelompokkontrol Dan kelompok eksperimen

\begin{tabular}{ccccc}
\hline Interval & \multicolumn{2}{c}{$\begin{array}{c}\text { Kelompok } \\
\text { Kontrol }\end{array}$} & \multicolumn{2}{c}{$\begin{array}{c}\text { Kelompok } \\
\text { eksperimen }\end{array}$} \\
\hline & $\begin{array}{c}\text { Frekuen } \\
\text { si }\end{array}$ & $\begin{array}{c}\text { Presentas } \\
\text { e (\%) }\end{array}$ & $\begin{array}{c}\text { Frekue } \\
\text { nsi }\end{array}$ & $\begin{array}{c}\text { Presentas } \\
\text { e }(\%)\end{array}$ \\
\hline $\mathbf{6 0 - 6 5}$ & 4 & $16 \%$ & 5 & $16,6 \%$ \\
\hline $\mathbf{6 6}-\mathbf{7 1}$ & 6 & $24 \%$ & 3 & $10 \%$ \\
\hline $\mathbf{7 2}-\mathbf{7 7}$ & 4 & $16 \%$ & 3 & $10 \%$ \\
\hline $\mathbf{7 8}-\mathbf{8 3}$ & 5 & $20 \%$ & 9 & $30 \%$ \\
\hline $\mathbf{8 4}-\mathbf{8 9}$ & 3 & $12 \%$ & 5 & $16,6 \%$ \\
\hline $\mathbf{9 0}-\mathbf{9 5}$ & 3 & $12 \%$ & 5 & $16,6 \%$ \\
\hline $\mathbf{9 6}>$ & 0 & $0 \%$ & 0 & $0 \%$ \\
\hline Jumlah & 25 & $100 \%$ & 30 & $100 \%$ \\
\hline
\end{tabular}

Dari tabel diatas dapat diketahui bahwa pada kelompok kontrol, skor postest terdapat 4 siswa yang mendapatkan skor antara $60-65$ dengan presentase $16 \%, 6$ siswa yang mendapatkan skor antara 66 - 71dengan presentase $24 \%, 4$ siswa yang mendapatkan skor $72-77$ dengan presentase $16 \%, 5$ siswa yang mendapatkan skor anatara $78-83$ dengan presentase $20 \%, 3$ siswa yang mendapatkan skor antara 84 - 89 dengan presentase $12 \%, 3$ siswa yang mendapatkan skor 90 - 95 dengan presentae $12 \%$. Sendangkan pada kelompok eksperimen terdapat 5 siswa yang mendapatkan skor antara 60 - 65 dengan presentase 16,6\%, 3 siswa yang mendapatkan skor antara $66-71$ dengan presentase $10 \%, 3$ siswa yang mendapatkan skor antara $72-77$ dengan presentase $10 \%, 9$ siswa yang mendapatkan skor antara $78-83$ dengan presentase $30 \%, 5$ siswa yang mendapatkan skor antara $84-89$ dengan presentase 16,6. 5 siswa yang mendapatkan skor antara 90 - 95 dengan presentase $16,6 \%$, .

Dengan rata-rata hasil belajar kelompok kontrol sebesar 74,52 dan rata-rata kelompok eksperimen 78,50. Perbedaan rata-rata kedua kelompok ini disebabkan karena adanya perlakuan belajar yaitu pada kelompok kontrol menggunakan model berbasis kemendikbud dan kelompok ekperimen dengan berbasis daerah tempat tinggal sekitar. dengan demikian dilihat dari perbedaan hasil rata-rata kelompok ekperimen lebih tinggi dari kelompok kontrol yang berarti bahwa terdapat peningkatan hasil belajar.

Teknik analisis data yang digunakan yaitu adalah uji beda rata-rata (uji t) dengan independent samples test. Distribusi uji t skor hasil belajar tematik kelompok kontrol dan kelomok eksperimen dapat dilihat pada tabel berikut ini.

\section{Independent Samples Test}

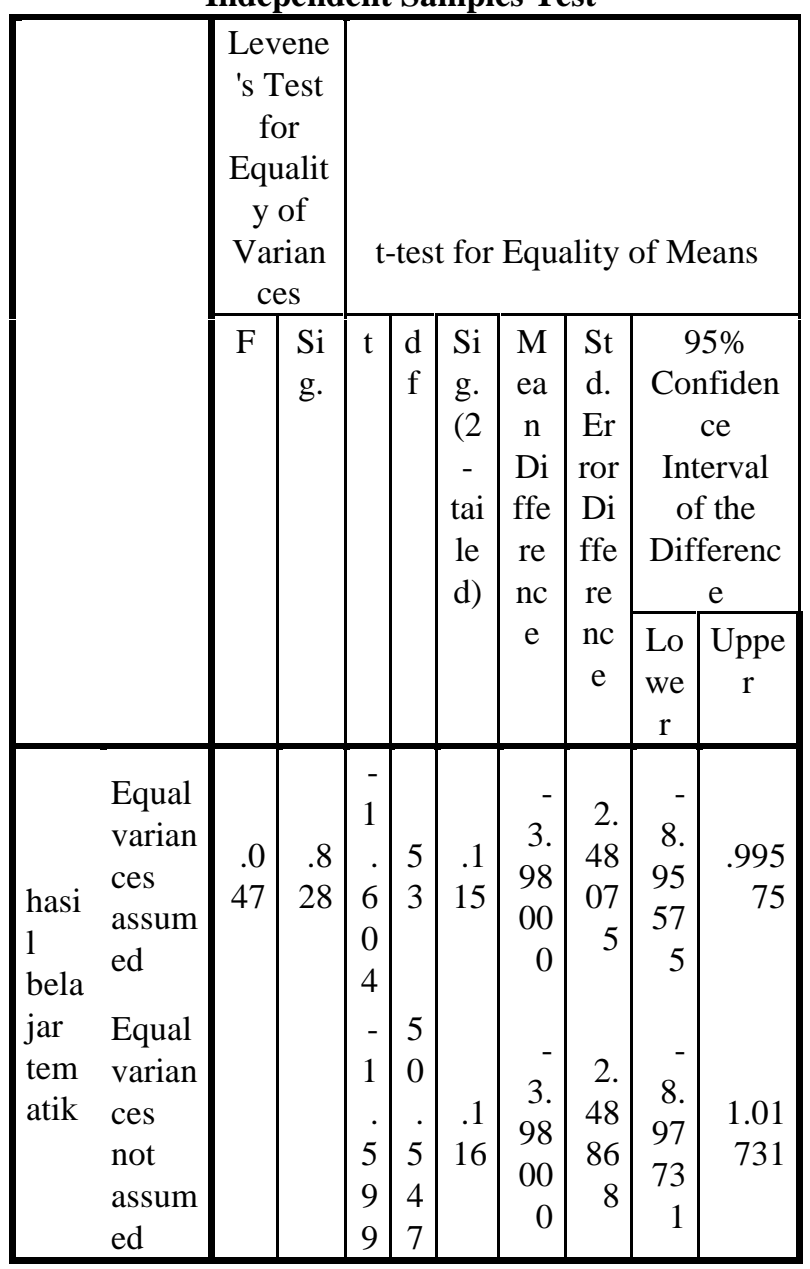

Tabel 4. Hasil uji t kelompok kontrol dan eksperime

Hasil uji $\mathrm{t}$ yang diperoleh dari $\mathrm{t}$ hitung sebesar 1604 dengan signifikansi sebesar $0,0115<0,05$ maka $\mathrm{H}_{\mathrm{a}}$ diterima artinya terdapat peningkatan hasil belajar menggunakan model berbasis daerah tempat tinggal sekitar. hal ini terjadi karena pada pembelajaran siswa selain 
belajar di dalam kelas, mereka juga melakukan kegiatan observasi, pengamatan secara langsung didaerah tempat tinggal sekitar. signifikansi sebesar $0,0115<0,05$, maka $\mathrm{H}_{\mathrm{a}}$ diterima artinya bahwa hasil belajar menggunakan model berbasis daerah tempat tinggal sekitar lebih tinggi dibandingkan dengan berbasis kemendikbud.

Hal ini diperkuat dengan penelitian yang dilakukan oleh Pringgondani A.T.W. (2016). Hasil penelitian menunjukkan signifikan terhadap hasil belajar siswa pada uji coba terbatas diperoleh hasil nilai $\mathrm{T}$ hitung sebesar 4,118 dengan nilai $\alpha=0,000<0,05$. Artinya kompetensi hasil belajar menggunakan Model Desain Pembelajaran Tematik Integratif Berbasis Lingkungan lebih tinggi dari pada model desain pembelajaran tematik integratif dari Pemerintah. Selain itu juga dibuktikan dengan hasil penelitian yang dilakukan Yusinta Dwi Ariyani dan Muhammad Nur Wangid (2016) menunjukkan hasil bahwa bahan ajar tematik integratif dengan tema "Lingkunganku Bersih dan Sehat" berbasis nilai karakter peduli lingkungan dan tanggung jawab untuk meningkatkan berpikir kritis serta nilai karakter peserta didik kelas 1 sekolah dasar.

Penelitian ini sejalan dengan penelitian yang dilakukan oleh Mulyadi, Marzuki, Andi (2015) bahwa preskriptif tugas belajar dilakukan guru dalam pembelajaran tematik terpadu berbasis lingkungan sangat membantu peserta didik untuk memperoleh kemampuan berpikir tingkat tinggi.

Pelaksanaan pembelajaran berbasis daerah tempat tinggal sekitar, nampak dalam aktivitas siswa dan hasil belajar berdasarkan catatan pengamatan, hasil belajar siswa kelompok eksperimen lebih tinggi saat melaksanakan pembelajaran di dalam dan luar kelas. Pembelajaran dimulai dengan penjelasan materi dan pembetukan kelompok di dalam kelas, kemudian siswa di ajak keluar kelas untuk melakukan kegiatan observasi di daerah tempat tinggal sekitar secara berkelompok setelah itu siswa diskusi untuk menyajikan hasil observasi dan wawancara dengan objek yang sudah ditentukan mengenai jenis-jenis pekerjaan dalam bentuk cerita yang termasuk tulisan non fiksi kemudian dipresentasikan kepada kelompok lain setelah itu siswa diberikan soal evaluasi.

Dalam kegiatan pembelajaran model berbasis daerah tempat tinggal sekitar, siswa berperan aktif dan mendapatkan pengalaman belajar yang bermakna karena siswa terjun langsung ke lapangan.

Jadi dari hasil penelitian yang telah dilakukan menunjukkan bahwa terdapat peningkatan hasil belajar dengan model berbasis daerah tempat tinggal sekitar pada pembelajaran tematik, tema jenis-jenis pekerjaan siswa kelas 4 SD Gugus Sidik Wacana kecamatan Ambarawa.

\section{Simpulan dan saran}

Dari hasil penelitian dan pembahsan dapat disimpulkan bahwa terdapat peningkatan hasil belajar menggunakan model berbasis daerah tempat tinggal sekitar dalam pembelajaran tematik hal ini terjadi karena pada pembelajaran siswa selain belajar di dalam kelas, mereka juga melakukan kegiatan observasi, pengamatan secara langsung di daerah tempat tinggal sekitar. peningkatan ini ditunjukkan dengan hasil uji $\mathrm{t}$ hitung 1604 dengan signifikansi sebesar 0,0115 $<0,05$, maka $\mathrm{H}_{\mathrm{a}}$ diterima artinya bahwa hasil belajar menggunakan model berbasis daerah tempat tinggal sekitar lebih tinggi dibandingkan dengan berbasis kemendikbud.

Saran yang diberikan adalah guru diharapkan menggunakan model tematik integratif berbasis daerah tempat tinggal sekitar dalam kegiatan pembelajaran tematik pada tema jenis-jenis pekerjaan, sehingga hasil belajar akan lebih meningkat dan siswa mendapatkan pengalaman belajar yang bermakna.

\section{Daftar Pustaka}

Azwar, S. 2011. Reliabilitas dan Validitas. Yogyakarta : Pustaka Pelajar.

Ariyani, Y. D., \& Wangid, M. N. (2016). Pengembangan Bahan Ajar Tematik Integratif Berbasis Nilai Karakter Peduli Lingkungan dan Tanggung Jawab. Jurnal Pendidikan Karakter, (1). 
Pringgodani, $\quad$ A.T.W.(2016). Pengembangan Model Desain Pembelajaran Tematik Integratif Berbasis Lingkungan (Doctoral dissertation, Program Studi Pendidikan Guru Sekolah Dasar FKIP-UKSW).

Wangid, M. N., Mustadi, A., Erviana, V. Y., \& Arifin, S. (2014). Kesiapan guru SD dalam pelaksanaan pembelajaran tematik-integratif pada kurikulum 2013 di DIY. Jurnal Prima Edukasia,2(2), 175-182.

Prastowo, A. (2017).Menyusun Rencana Pelaksanaan Pembelajaran (RPP) Tematik Terpadu. Kencana.

Ariyani, Y. D., \& Wangid, M. N. (2016). Pengembangan Bahan Ajar TematikIntegratif Berbasis Nilai Karakter Peduli Lingkungan dan Tanggung Jawab. Jurnal Pendidikan Karakter, (1).

Abduh, M. (2015). Pengembangan perangkat pembelajaran tematik-integratif berbasis sosiokultural di sekolah dasar. Jurnal Penelitian Ilmu Pendidikan, 8(1).

Mawardi, M. (2019). Peningkatan Kebermaknaan dan Hasil Belajar Siswa melalui Desain Pembelajaran Tematik Terpadu Berbasis Projek di Sekolah Dasar. Jurnal Riset Teknologi dan Inovasi Pendidikan, 2(1), 1-14.

Kristiantari, M. R. (2015). Analisis kesiapan guru sekolah dasar dalam mengimplementasikan pembelajaran tematik integratif menyongsong kurikulum 2013. JPI (Jurnal Pendidikan Indonesia), 3(2).
Budiharto, B., Handayani, S., \& Triyoto, T. (2017). Studi Deskriptif Analisis terhadap Bimbingan Guru dalam Meningkatkan Penguasaan Konsep IPA dan Hasil Belajar Siswa Kelas V SD Padapembelajaran Ipaberbantuan Pendekatan Keterampilan Proses. JURNAL PENDIDIKAN SAINS (JPS), 5(1), 10-21.

Usman, A. (2015). Implementasi Pembelajaran Tematik Terpadu Berbasis Lingkungan untuk Perolehan Kemampuan Berpikir TingkatTinggi di SD. Jurnal Pendidikan dan Pembelajaran, 4(3).

Novianto, A., \& Mustadi, A. (2015). Analisis buku teks muatan tematik integratif, scientific approach, dan authentic assessment sekolah dasar. Jurnal Kependidikan: Penelitian Inovasi Pembelajaran, 45(1).

Muryaningsih, S., \& Mustadi, A. (2015). Pengembangan RPP Tematik-Integratif untuk Meningkatkan Karakter Kerja Keras di Kelas 1 SD N 2 Sokaraja Tengah. Jurnal Prima Edukasi,3(2), 190-201.

Mustamilah.2015.peningkatan keterampilan proses dan hasil belajar model problem based learning pada subtema merawat tubuhku siswa kelas 1 SD Negeri 1 Gonoso-Wonosegoro. Jurnal Scholaria,vol: 5 no: 1.

Mawardi, M. (2018). Merancang Model dan Media Pembelajaran. Scholaria: Jurnal Pendidikan dan Kebudayaan, 8(1), 2640. 